\title{
The Diffusion of Merit Aid Programs Across State Lines
}

\author{
J.W. Decker \\ The Hunt Institute
}

\author{
Bruce D. McDonald, III \\ North Carolina State University
}

States award merit aid scholarships to motivate student achievement. Merit aid programs also eliminate the movement of high-performing students to out-of-state institutions and increase access to postsecondary education for low-income families. Despite the perceived benefits of adopting a program, only 34 states have chosen to do so. Using an event history analysis approach and data for all 50 states from 1992 to 2015, we explore how external mechanisms influence the decision of a state to adopt a program. The results show that states adopt to gain a competitive edge. However, that decision is heavily influenced by the decisions of others, with trends in regional and national adoptions increasing the likelihood of a state adopting.

Keywords: merit aid scholarships, education policy, policy diffusion, event history analysis

\section{INTRODUCTION}

An individual's economic and social well-being is directly affected by their level of education (Perna \& Jones, 2013). A university degree has become a requirement for most employment opportunities (Perna \& Finney, 2014), leading to an increased focus in politics on students obtaining access to higher education. Unfortunately, the cost of a university degree has also risen, with the average cost of public four-year tuition increasing from about $\$ 8,600$ per year in 1993 to nearly $\$ 19,500$ in 2017 when adjusted for inflation (National Center for Education Statistics [NCES], 2019). This is roughly a $225 \%$ increase in the cost of tuition, which has created an economic gap between those who have the resources to pursue higher education and those who do not. In 2017, only 51\% of high school graduates from low-income families enrolled in a higher education program (NCES, 2019). For many low-income students, financial aid is the primary determinant of whether they pursue a college degree (Leeds \& DesJardins, 2015; Perna \& Jones, 2013).

States have attempted to fill the gap in student financial aid for postsecondary education through publicly funded scholarship and grant programs, one of which is merit aid scholarships (Perna \& Jones, 2013). Merit aid scholarships are awarded to students based on their academic performance in high school, as represented by their GPA and standardized test scores (Dynarski, 2002). To support the adoption of these merit aid programs, policymakers have touted the policy goals of keeping students in the state, motivating high school students with achievement goals, and expanding college access and affordability (Leeds \& DesJardins, 2015). Since Georgia adopted the first state merit aid program in 1993, an additional 33 states 
have adopted some form of merit aid scholarships (Dynarski, 2002; Sjorquist \& Winters, 2015). Despite the widespread adoption of these programs, little is known within the education policy literature on why some states have adopted and others have not.

To address the gap in the literature on merit aid and the diffusion of education policy, this study seeks to answer the question: Why do states adopt merit aid scholarship programs? It is hypothesized that states will adopt merit aid to gain a competitive edge over other states. Economic growth depends on the expansion of human capital. The provision of merit aid is a means of incentivizing the pursuit of that capital and encouraging college students to remain in the state after graduation. It is also expected that states will adopt merit aid based on the process of policy learning. That is, states observe the policies and programs that other states in the union adopt and choose to implement the most successful ones. A model of the innovation and diffusion framework is adopted to investigate the determinants of merit aid adoption. The model is then estimated using an event history analysis approach with data from all 50 states from 1992 to 2015.

The results of the analysis show that merit aid programs are diffused across states by external mechanisms related to state competition and policy learning. For the competition mechanism, we found evidence that states use the programs to increase the educational capacity of their labor force. On the issue of policy learning, our results show that states look regionally and nationally for policy solutions and ideas. States, however, are more likely to compete with the immediate neighbors, as the adoptive behavior of neighboring states was negatively associated with a state's adoption decision. This suggests that the talking points frequently used to support program adoption may not actually influence policymakers' decisions.

The remainder of this study is organized as follows: The first section introduces the creation of merit aid scholarships and their goals and outcomes. Next, utilizing the mechanisms of policy diffusion as established within the innovation and diffusion literature, a theoretical framework for the diffusion of merit aid is established. The third section describes the methodology and data used in the analysis. The results of that analysis are provided in the section that follows. Finally, the paper concludes with a discussion of the results and their implications for the literature on state merit aid and policy diffusion.

\section{FORMATION OF MERIT AID PROGRAMS}

As stated above, financial aid is a key factor in promoting college enrollment, persistence, and completion (Dynarski, 2003; Heller, 2006; Scott-Clayton, 2015). Since the signing of the Higher Education Act (HEA) of 1965, many states and the federal government have provided financial aid to students entering higher education. The overwhelming majority of financial aid offered as a result of this act has been needbased (Scott-Clayton, 2015). However, through the decades, the emphasis on funding higher education has shifted from the government's responsibility to the student (Hu \& John, 2001). This shift in funding responsibility has resulted in inequalities between high and low-income students and students from different racial populations. As a result, state governments started to shift their thinking around higher education funding in the 1990s in order to decrease these inequities (Dynarski, 2003; Hu \& John, 2001).

In 1993, Georgia became the first state to codify offering aid based on a student's merit rather than need (Long, 2004). State legislators argued that by providing merit-aid, Georgia's benefits would be threefold. First, it would keep the brightest students in the state, which creates a more educated workforce. Second, it would support college access and affordability, making funding available for a broader range of students. Finally, a merit aid scholarship would also encourage high school students towards high school graduation since they would know higher education funding was available for them regardless of income (Leeds \& DesJardins, 2015; Pingel, Sponsler, \& Holly, 2018).

Lawmakers proposed this idea to Georgia residents through a ballot initiative in the 1992 election. Georgia voters passed the referendum, and in 1993, the state adopted a lottery system with proceeds earmarked for educational programming, which included the first state-funded merit aid program, the Helping Outstanding Pupils Educationally (HOPE) scholarship (Dynarski, 2000). This scholarship provided full tuition, fees, and a book allowance to Georgia students' who had a B average or above in high 
school and chose to attend an in-state public university. This created a template for how states could offer merit aid funding in a sustainable way to their residents (Long, 2004).

During the height of merit aid proposals in the mid-2000s, thirty-four states had implemented merit aid funding (Leeds \& DesJardins, 2015). These programs and their benefits varied from state to state, with financial support ranging from full tuition to $\$ 500$ per semester (Cornwell, Mustard, \& Sridhar, 2006; Heller \& Marin, 2005; Ness, 2010). The merit requirements also vary by state. Some states focus solely on high school grade point average, and others combine grades with standardized test scores, such as the ACT or SAT, to determine eligibility (Cornwell, Mustard, \& Sridhar, 2006; Sjoquist \& Winters 2012). Funding a merit scholarship program proved more costly to some states than others, as states have tinkered with the total amount of funding and merit requirements over the years to make their programs more sustainable. Four states (Illinois, Maryland, Michigan, and Washington) implemented a merit aid scholarship system, but eventually repealed it due to cost and lack of results (Sjoquist \& Winters, 2012).

In summary, merit aid programs aim to increase overall in-state college enrollment and create goals that motivate both high school and college student achievement (Heller \& Marin, 2004; Scott-Clayton, 2011); however, these programs appear to do little in improving college access and affordability for underrepresented students, as they are not means-tested (Leeds \& DesJardins, 2015; Perna \& Jones, 2013; Scott-Clayton, 2011). This review of merit aid programs across different states highlights the complicated history and outcomes of these policies. Without clear and consistent results, it is necessary to explore the diffusion mechanisms that support the growth of merit aid programs across state governments. By better understanding the factors that supported the diffusion of merit aid programs, inferences can be drawn about other state policies that show mixed results based on the jurisdiction. The rest of this section describes the innovation and diffusion framework using previous scholarly literature before positing hypotheses based on the factors of innovation and diffusion.

\section{The Innovation and Diffusion Framework}

We turn to the extant literature to understand the factors that influence whether a state adopts merit aid scholarship programs. Beginning with Walker (1969), scholars have explored the issue of how and why states adopt new policies. To aid in this exploration, Berry and Berry $(1990,2014,2018)$ developed the Innovation and Diffusion Framework (IDF) to explain how policy solutions spread across governmental lines. According to the framework, policy diffusion occurs when the choices and actions of one government influence the policies or behaviors of another. The scope of this influence includes a number of mechanisms that promote the spread of a policy, including coercion, governmental competition, policy innovation, policy learning, and other normative pressures. While each mechanism contributes to the decision to adopt a policy, multiple mechanisms are typically needed to make the diffusion of a policy successful. The circumstances drive the choice of mechanisms behind the decision to adopt and conditions of a government (Kim, McDonald, \& Lee, 2018; McDonald \& Gabrini, 2014; Walker, Avellaneda, \& Berry, 2011). Such influences include the motivation behind adopting a policy, the resources available or obstacles prohibiting adoption, existing policy arrangements, and a variety of external factors (Berry \& Berry, 2018; Berry, Berry, \& Foster, 1998).

The literature supporting the IDF has found that the mechanisms that influence the diffusion of a policy may either be internally or externally focused (Berry \& Berry 2018). While internal influences are centered on the structure and politics of a government as a determining factor on whether a government adopts a policy (see Kim, McDonald, \& Lee, 2018), external factors focus on the impact that the environment in which the state operates has on adoption decisions (see Shipan \& Volden, 2008). While this study controls for the internal dynamics of a state, our primary focus is on the role that the external mechanisms play in the diffusion of merit aid programs. According to Berry and Berry (2014) and Shipan and Volden (2008), four external mechanisms influence policy innovation and diffusion. These are: policy learning, which involves a government learning of policy solutions by observing how others have engaged the policy arena; competition, whereby policies are adopted in order to remain competitive for business development or population growth; imitation, where policies are adopted because other governments have adopted them; 
and coercion, where policies are adopted by governments who were coerced into policy action. However, Berry and Berry $(2014 ; 2018)$ are quick to note that multiple mechanisms may underlie policy diffusion.

The diffusion of merit aid programs across states is unique within the policy adoption literature. It relies on both state competition and policy learning as the mechanisms of innovation and diffusion. States rely on an educated, well-trained population to encourage economic development within their borders, leading policymakers to make policy decisions that incentivize retaining an educated workforce. At the same time, policymakers look to other states for potential policy solutions to the human capital problems they face.

Beginning with the competition mechanism, we argue that states compete for the human capital that their residents, particularly their educated residents, provide. Therefore, to gain votes and be reelected, politicians must give the appearance that they are working to solve constituent problems (Kim, Shon, \& McDonald, 2021; Young, Wiley, \& Searing, 2020), and one way of accomplishing this is the expansion of the region's economy (see McDonald, Decker, \& Johnson, 2021; Prillaman \& Meier, 2014). However, the desire for economic expansion is great, leading states to compete against each other to expand within their borders (Berry \& Baybeck, 2005; Boehmke \& Witmer, 2004; Decker, 2021).

A central component of economic development is the stock of human capital that a government has at its disposal (Becker, 1993; McDonald, 2021; Savvides \& Stengo, 2009). For a business to expand, a skilled labor force is needed to accommodate the increased demand for labor that the expansion poses. When a sufficient stock of human capital is available, businesses can enter into a state's economy and quickly become productive. However, when the supply of human capital is not available, businesses must invest in training programs to employ a skilled workforce. As a result, businesses are most likely to pursue expansion and development in states with a trained workforce from which they can draw (see Becker, 1993), creating competition between states for an educated population. As states compete for economic advantage, policymakers may develop programs to retain a competitive edge over other states. One way of creating this competitive edge is by offering merit aid.

As previously noted, merit aid programs offer scholarships and financial assistance to state residents who meet and maintain certain qualifications, typically measured as a minimal GPA. The decision of a state to provide merit-aid as a competitive tool is not merely reactive but can also be preemptive and strategic (see Baybeck, Berry, \& Siegel, 2011; Shipan \& Volden, 2012). These programs have two impacts regarding state competition. First, they incentivize students to stay in the state for their education rather than moving out of state for college. Previous research has noted that students tend to reside in the state where they pursued higher education rather than returning to their home state after graduation (Sjoquist \& Winters, 2014). Because of this tendency, incentivizing students to stay in-state ensures that skilled talent remains available for businesses seeking to expand or develop. Second, the cost of attending a college or university often serves as a barrier to entry. By offering merit aid scholarships, states can reduce the cost of pursuing higher education while also expanding the stock of human capital available (Cohen-Vogel, Ingle, Levine, \& Spence, 2008; Heller, 2006; Heller \& Merin, 2004). Based on the above discussion, we adopted the following two hypotheses:

$\boldsymbol{H}_{1}$ : States with lower levels of educational attainment are more likely to adopt merit aid programs.

$\boldsymbol{H}_{2}$ : States with higher levels of students pursuing education in another state are more likely to adopt merit aid programs.

The second mechanism that influences the decisions of states to adopt merit aid programs is policy learning. Previous research into policy diffusion has argued that the decision of a government to adopt a policy is influenced by the policies that others have adopted (Berry \& Berry, 2018; Checkland, et al., 2021; Kim, McDonald, \& Lee, 2018; Volden, Ting, \& Carpenter, 2008). The innovation of a policy solution can be both costly and unpredictable, creating a high level of risk to the policymakers who encourage innovation (Berry \& Berry, 1990). Rather than accept this risk, Volden, Ting, and Carpenter (2008) suggest that policymakers may take shortcuts by focusing on what other governments have done to address the issue (see also Bailey \& Rom, 2004; Doyle, 2006; Shipan \&Volden, 2008). After all, most of the challenges that 
states face are not unique to any one state. Rather, the challenges of one state are often reflective of the challenges of other states. For example, Ohio is not alone in looking for answers to their opioid crisis, nor is Florida alone in dealing with challenges related to property damage from extreme weather events. By examining states with similar profiles, policymakers can introduce a policy that is better suited for the specific circumstances and gain knowledge about how constituents may respond to a policy and the risks associated with it (Boehme, 2000; Boehmke \& Witmer, 2004).

When the difference of a policy occurs based on the policy learning mechanism, the adopting government is faced with a problem whenever a solution is needed. Rather than innovate their solution, policymakers look to others on how they managed a similar situation. The extant literature is mixed in terms of whom policymakers may look at for mimicry. Some have suggested that learning primarily follows a government's borders (Lacy \& Tandberg, 2014). Neighboring governments are most likely to have similar issues and political and demographic conditions, making them ideal candidates for replicating a solution. This same literature has pointed to the proximity of neighbors in terms of an increased likelihood of being aware of what the neighbor has done and increased pressure to follow suit (see McLendon, Heller, \& Young, 2005; McLendon, Hearn, \& Deaton, 2006). Others have pointed to a more regional influence, as policymakers engage with each other and learn from each other at regional conferences and events (see McLendon, Hearn, \& Deaton, 2006; Walewr, 1969). For governments concerned about maintaining a competitive advantage over their neighbors, a regional diffusion would allow a government to maintain their edge while minimizing the risks associated with innovation. Still, others have argued for a more national-based diffusion, where the networks such as the National Conference of State Legislatures and technology have reduced the distance between governments and allowed for an easier spread of policy solutions (see Berry \& Berry, 2018).

In the context of our study, the diffusion of merit aid programs due to policy learning is straightforward. Policymakers are interested in improving educational achievement within their state, but developing programs to combat low levels of achievement is inherently risky. Not only is the innovation of a new policy time-consuming and costly, but there is also no certainty that the policy developed would successfully address the problem. Rather than innovate, policymakers are likely to encourage policy learning for a policy solution. States may attempt to increase educational attainment by using policies that successfully increase achievement in other states (Scott-Clayton, 2011). As Angrist and Lavy (2002) found, higher educational attainment is linked to the incentive structure in place and developing incentives for high school students through policy may be one way to raise graduation rates. For example, Cornwell et al. (2010) found that merit aid scholarships raised the high school graduation rate in Georgia, the first state to adopt such a program. As policymakers see other states succeed in increasing their graduation rates through merit aid programs, the Innovation and Diffusion Framework policy learning mechanism suggests that they should be more likely to adopt similar policies. Accordingly, we adopted the following three hypotheses:

\section{$\mathrm{H}_{3}$ : The larger the share of neighboring states with merit aid programs, the more likely a state is to adopt a merit aid program.}

$\boldsymbol{H}_{4}$ : The larger the share of regional states with merit aid programs, the more likely a state is to adopt a merit aid program.

\section{$\mathrm{H}_{5}:$ The larger the share of states with merit aid programs, the more likely a state is to adopt a merit aid program.}

Our final hypothesis attempts to understand how competition and learning can both influence policy adoption. Lawmakers do not only look at other states to understand what policies work well under similar conditions, but they also want to ensure their state stays competitive in the modern economy. Further, states may learn how to be competitive through observing how other states choose to implement policies. Both mechanisms are not mutually exclusive, and this leads to the final hypothesis: 
$H_{6}:$ The mechanisms of learning and competition are likely to occur simultaneously rather than occurring independently from each other.

\section{MODEL AND DATA}

The primary goal of the present study was to determine what factors influence a state to adopt merit aid. To accomplish this goal, we utilized an event history analysis (EHA) methodological approach. EHA is concerned with patterns and causes of qualitative changes (or "events") at a given point in time. The intent is to determine how a variable, or set of variables, affected the probability that an organization would transition into a new social state. This understanding of the event comes from a longitudinal record of a sample's data, referred to as its "event history." Because EHA is the study of the cause of an event, an event history should include all possible explanatory variables. Some of these explanatory variables may be relatively constant over time (e.g., the Democratic share of the population or region) and some of which may exhibit large fluctuations (e.g., population and revenue). An event history is further distinguished by its time period, such that continuous time models measure the precise time for an event and discrete time models measure an event within a specified period of analysis (i.e., months, years, etc.).

A central component of an EHA is its "hazard rate." The hazard rate is the probability that a state at risk of adopting a merit aid program will experience the adoption (or event) at a particular point in time. It is assumed that the hazard rate not only varies by state, but also by year. Instead, the rate is determined by the set of independent variables from the event history. As a probability of an event, the hazard rate is an unobserved variable that varies between " 0 " and " 1 ." Thus, the observed variable used in estimation is a dichotomous dummy variable that accounts for the absence or occurrence of an event (coded as a " 0 " or "1," respectively).

The application of EHA to the issue of state merit aid programs is accomplished in two steps. First, the risk set must be defined; and, second, the adoption model must be established. Given the focus of the study on state-level adoption, the sample was confined to all 50 states in the United States for the years 1992 to 2015. Thus, this sample covers the innovation of merit aid by Georgia in 1993 and its subsequent diffusion, including the most recent adoption by Connecticut in 2014. One aspect of this study that is unique from previous studies on policy adoption is that once a state adopts a merit aid policy, it is also at risk of its deadoption. In our study, four states chose to adopt and then repudiate a merit aid program. ${ }^{1}$ An overview of which states have adopted merit aid programs is provided in Figure 1.

FIGURE 1

\section{MAP OF STATES WITH MERIT AID PROGRAMS}

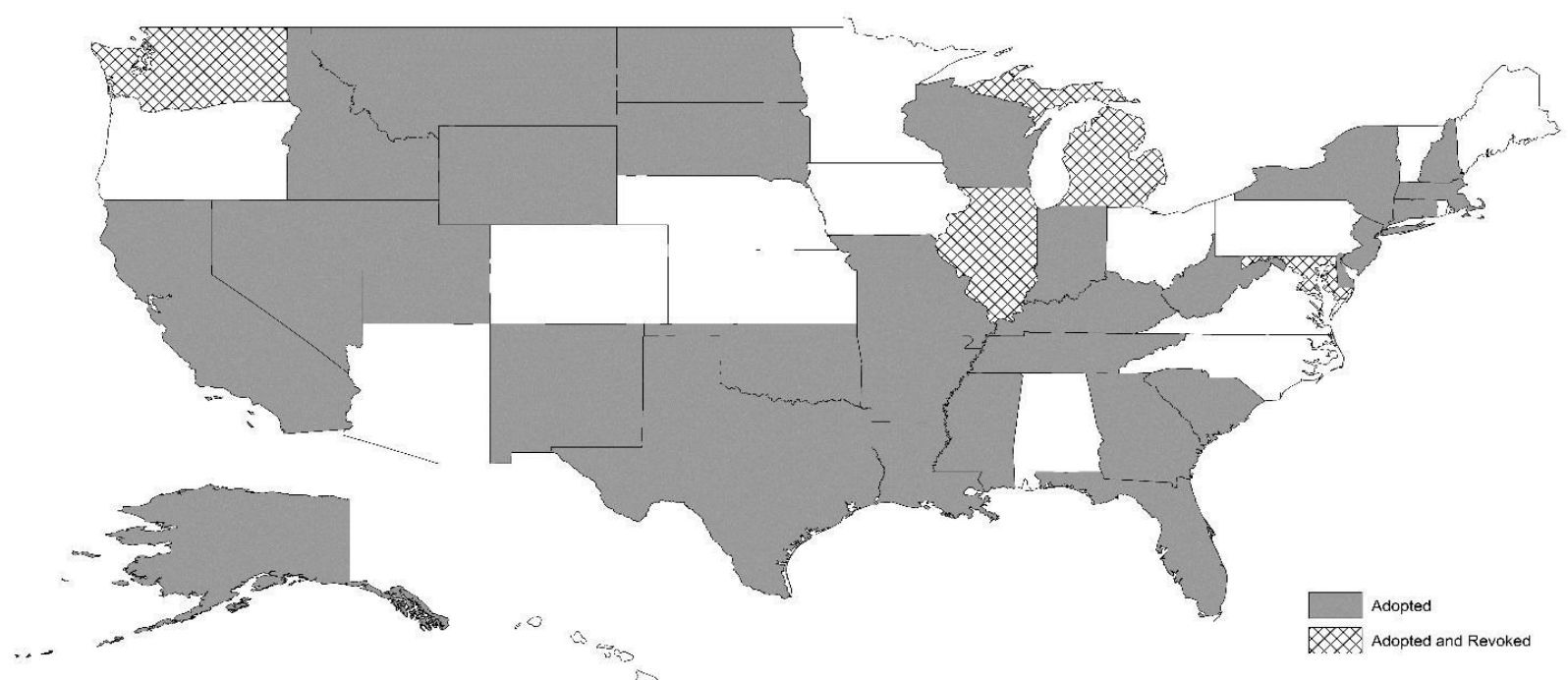


Regarding the policy adoption model, the previous discussion on merit aid, learning and competition amongst states, as well as the extant literature on policy adoption (see Berry \& Berry, 2007), suggest the following model for policy analysis of state adoption decisions:

Adoption $_{i, t}=\Theta\left(\beta_{1}\right.$ Competition $_{i, t}+\beta_{2}$ Learning $_{i, t}+\beta_{3}$ Governmental $_{i, t}+\beta_{4}$ Political $_{i, t}+$ $\beta_{5}$ Demographic $_{i, t}+6$ Economic $\left._{i, t}\right)$

where the dependent variable adoption is the hazard rate of the probability that state $i$ adopts a merit aid program in year $t$. Furthermore, $\theta$ denotes the cumulative normal distribution of the model. The hazard rate is measured as a dummy variable where a " 0 " or a " 1 " is used to signify the absence or presence, respectively, of a merit aid program. Estimation of the model takes the form of a pooled cross-sectional probit. Having previously established the risk set, data on the years and state of merit aid adoptions were obtained from the extant literature on merit aid (see Copeland \& Mamiseishvili, 2017; Domina, 2014; Heller \& Marin, 2004; Ness, 2010; Sjoquist \& Winters, 2012). The simple statistics for all study variables are shown in Table 1.

TABLE 1

SIMPLE STATISTIC

\begin{tabular}{|c|c|c|c|c|}
\hline Variable & Mean & Std. Dev. & Min. & $\operatorname{Max}$ \\
\hline \multicolumn{5}{|l|}{ Dependent Variable } \\
\hline Adoption & 0.4217 & 0.4940 & 0 & 1 \\
\hline \multicolumn{5}{|c|}{ State Competition Variables } \\
\hline Attainment & 0.2160 & 0.0536 & 0.0950 & 0.4040 \\
\hline Out of State & 0.2114 & 0.1136 & 0.0630 & 0.5790 \\
\hline \multicolumn{5}{|l|}{ Policy Learning Variables } \\
\hline Neighbors & 0.4172 & 0.3145 & 0 & 1 \\
\hline Region & 0.4223 & 0.2533 & 0 & 0.8125 \\
\hline National & 0.4217 & 0.2159 & 0 & 0.6000 \\
\hline \multicolumn{5}{|c|}{ Governmental Characteristics } \\
\hline Counties & 63.7800 & 45.4547 & 3 & 254 \\
\hline Municipalities & 387.9975 & 320.8994 & 1 & 1,298 \\
\hline Special Districts & 708.6583 & 685.8576 & 14 & 3,327 \\
\hline Efficiency Ratio & 0.9658 & 0.2080 & 0.4447 & 4.2162 \\
\hline IGR Dependence Ratio & 0.2620 & 0.0722 & 0.1104 & 1.0326 \\
\hline Debt Service Burden & 0.5356 & 0.3052 & 0.0832 & 2.4550 \\
\hline \multicolumn{5}{|l|}{ Political Characteristics } \\
\hline Democratic Legislature & 0.4167 & 0.4932 & 0 & 1 \\
\hline Democratic Governor & 0.4608 & 0.4987 & 0 & 1 \\
\hline New Term & 0.2600 & 0.4388 & 0 & 1 \\
\hline Unified System & 0.5400 & 0.4986 & 0 & 1 \\
\hline \multicolumn{5}{|c|}{ Demographic Characteristics } \\
\hline Minority Population & 0.1682 & 0.1200 & 0.0131 & 0.7042 \\
\hline Population Density & 186.7555 & 252.4634 & 1.0317 & 1206.2280 \\
\hline Incorporated Population & 0.5814 & 0.1647 & 0.0760 & 0.8820 \\
\hline
\end{tabular}




\begin{tabular}{|l|c|c|c|c|}
\hline \multicolumn{5}{|l|}{ Economic Characteristics } \\
\hline Income & $40,828.90$ & $7,257.72$ & $25,149.00$ & $68,287.00$ \\
\hline GSP & $47,950.41$ & $10,020.54$ & $28,335.29$ & $87,714.84$ \\
\hline Unemployment & 0.0565 & 0.0188 & 0.0230 & 0.1370 \\
\hline
\end{tabular}

All financial variables are expressed in 2015 per capita dollars

Central to this sample is the issue of accounting for the diffusion of merit aid programs through competition and policy learning. To account for diffusion by competition for an educated workforce, we utilize two variables: attainment and out of state. Attainment refers to the level of educational attainment within a state and is operationalized as the percentage of adults with a bachelor's degree. Out of state reflects the pursuit of educational attainment outside a student's state of residency and is operationalized as the share of a state's college attending residents who are attending a college or university in a different state. Data on educational attainment and student enrollments are from the National Center for Education Statistics.

To account for diffusion by learning about the policy options, we adopt three measurements: neighbors, regional, and national. The variable neighbors reflect the share of states with touching borders (or neighbors) that have adopted merit aid. Regional reflects the share of states within their respective U.S. Census regions that have adopted a merit aid program. Lastly, the variable national reflects the share of all states that have adopted a merit aid program. The measurement of the diffusion variables utilizes the data on merit aid adoptions previously outlined.

Next, attention is turned to the measurement of the control variables for our study, beginning with governmental conditions. Influencing a state's governmental behavior is the presence and type of other governments within its border. The variables counties, municipalities, and special districts reflect the number of the respective type of local government within a state. The state's fiscal health is also included to depict its capacity to fund merit aid programs. Given that no clear and consistent measurement exists (Maher, Ebdon, \& Bartle, 2020; McDonald, 2017, 2019), ${ }^{2}$ three broad indicators based on data available were adopted here. These are: efficiency ratio (measured as the ratio of total expenses to total revenue), the intergovernmental revenue (IGR), dependence ratio (measured as the ratio of IGR to total revenue), and debt service burden (measured as the ratio of total debt service to total revenue). The number of local governments within a state and state financial data is from the U.S. Census Bureau's Census of Governments.

The second group of control variables captures the political conditions of a state. We captured the political conditions with the variables Democratic legislature, Democratic governor, new term, and unified system. Democratic legislature refers to the political environment of the state's legislature. It is measured using a dummy variable, where a " 1 " signifies that the legislature has a Democratic majority and a " 0 " signifies Republican or split control. Similarly, Democratic governor accounted for the political control of the state's executive, and we measured it with a dummy variable, where a "1" represents the presence of a Democratic governor in the given year and a " 0 " illustrates a Republican or independent governor. Data on the Democratic control of the legislature is from the National Council of State Legislatures and information on the party affiliation of the governor's office is from the National Governors Association.

Additionally, administrative change may impact innovation, so we will account for the first year of a new governor in a state with the dummy variable new term, where a " 1 " is assigned for the year following the election of a new governor and a " 0 " assigned to all other years. Coding is again based on data from the National Governors Association. The composition of a state's university system also varies, with some states adopting a more centralized system and others adopting a decentralized approach. We account for this with the variable unified system, where a state with a unified university system is coded as a " 1 ." Any state that has a split university system or multiple systems in a particular year will be coded " 0 ." The data on the presence or absence of a unified system are from the National Center for Education Statistics.

Next, three variables were included to control for the demographic variations of states without the country. Minority population refers to the non-white share of the total population and incorporated population refers to the share of the population that live in incorporated areas. Finally, the variable 
population density refers to the population of the state per square mile. All population estimates, and the square land miles, come from the U.S. Census Bureau.

The remaining group of variables is related to the economic conditions of the state. These variables are gross state product (GSP), income, and unemployment. GSP is measured as the state's gross, per-capita product, and income is measured as the state's per-capita personal income. In addition, these variables are adjusted for 2015 levels of inflation. Both variables are derived from the U.S. Department of Commerce's Bureau of Economic Analysis. Finally, unemployment is measured as the annual average of the unemployed share of the state's labor population and is obtained from the U.S. Department of Labor's Bureau of Labor Statistics.

\section{RESULTS}

Using the data and model previously discussed, the results of the event history analysis were estimated using a pooled time-series-cross sectional probit. The results of the analysis are presented in Table 2 . Overall, the state merit aid programs adoption model was statistically significant: both the log-likelihood and chi-square indicated that the model fit the data well. Additionally, the results commonly found in the policy diffusion and education policy literatures were present in this analysis, with the signs of the variables being consistent with what those literatures hypothesize, further supporting the analysis results.

TABLE 2

EVENT HISTORY ANALYSIS RESULTS

\begin{tabular}{|c|c|c|c|c|}
\hline Variable & Estimate & Std. Error & $z$ & $P>|z|$ \\
\hline \multicolumn{5}{|l|}{ State Competition Variables } \\
\hline Attainment $\mathrm{t}-1$ & 7.4340 & 3.0284 & 2.4500 & 0.0070 \\
\hline Out of State $t_{-1}$ & -13.8222 & 5.4872 & -2.52 & 0.0060 \\
\hline \multicolumn{5}{|l|}{ Policy Learning Variables } \\
\hline Neighbors t-1 & -2.2146 & 1.0036 & -2.2100 & 0.0135 \\
\hline Region $_{\mathrm{t}-1}$ & 6.8886 & 2.2553 & 3.0500 & 0.0010 \\
\hline National $\mathrm{t}-1$ & 6.2534 & 1.8693 & 3.3500 & 0.0005 \\
\hline \multicolumn{5}{|c|}{ Governmental Characteristics } \\
\hline Counties $_{t}$ & 0.0110 & 0.0125 & 0.8800 & 0.189 \\
\hline Municipalities $_{\mathrm{t}}$ & -0.0069 & 0.0024 & -2.8700 & 0.0020 \\
\hline Special Districts $_{t}$ & 0.0013 & 0.0009 & 1.3500 & 0.0885 \\
\hline Efficiency Ratio $t-1$ & 2.8161 & 1.5200 & 1.8500 & 0.032 \\
\hline IGR Dependence Ratio $t-1$ & -0.1838 & 4.5867 & -0.0400 & 0.4840 \\
\hline Debt Service Burden ${ }_{t-1}$ & -4.1659 & 1.2964 & -3.2100 & 0.0005 \\
\hline \multicolumn{5}{|l|}{ Political Characteristics } \\
\hline Democratic Legislature $_{t}$ & -3.0077 & 0.5656 & -5.3200 & 0.0000 \\
\hline Democratic Governor $_{t}$ & 0.4630 & 0.2335 & 1.9800 & 0.0235 \\
\hline New Term $t$ & -0.0354 & 0.2272 & -0.1600 & 0.4380 \\
\hline Unified System $_{t}$ & 0.7039 & 1.0721 & 0.6600 & 0.2550 \\
\hline \multicolumn{5}{|c|}{ Demographic Characteristics } \\
\hline Minority Population $_{t}$ & 7.2148 & 3.6066 & 2.0000 & 0.0225 \\
\hline Population Density $\mathrm{t}$ & 0.0008 & 0.0028 & 0.2900 & 0.3780 \\
\hline Incorporated Population $_{\mathrm{t}}$ & 0.5829 & 0.8268 & 0.7100 & 0.2405 \\
\hline
\end{tabular}




\begin{tabular}{|l|c|c|c|c|}
\hline Economic Characteristics \\
\hline Income $_{\mathrm{t}-1}$ & 0.0003 & 0.0001 & 2.9300 & 0.0015 \\
\hline $\mathrm{GSP}_{\mathrm{t}-1}$ & -0.0000 & 0.0001 & -0.42 & 0.3380 \\
\hline Unemployment $\mathrm{t}-1$ & 0.9174 & 0.2489 & 0.0100 & 0.4605 \\
\hline Constant & -15.7069 & 3.2348 & -4.8600 & 0.0000 \\
\hline $\log$ likelihood $=-92.1702 ;$ Wald $\chi^{2}=235.6200 ;$ Prob $>\chi^{2}=0.0000$ \\
\hline
\end{tabular}

The most important of the results relate to the mechanisms of state competition and policy learning. Through the external mechanism of state competition, it had been hypothesized that states would use merit aid programs to improve the stock of human capital available for use by the private sector. Looking at our results, however, we found significant, albeit conflicting, support for our hypotheses. Attainment, which reflects the desire of a state to increase its current stock of human capital, was significant and positive. Conversely, the results for out of state, which reflects the willingness of a state to incentivize the pursuit of an in-state college degree, were significant but negative. We believe this reflects a desire to improve the educational capacity of a state's residents, but an acceptance that competition across state lines may be in vain. Out-of-state tuition rates are typically higher than what a student would be if they attended a university on an in-state basis. For these students, the cost of attendance is likely to be a secondary concern, with the funds available through a merit aid program unlikely to sway their attendance decision. Accordingly, the combination of results suggests that states compete by focusing their resources on improving their current capacity rather than expanding the base.

Next, we turn our attention to the measures for the policy learning mechanism, which accounts for the diffusion of merit aid programs from one state to another. The Innovation and Diffusion Framework posits that as a policy change or revision of a government is considered, policymakers are likely to look at other governments that have previously adopted a similar policy (Berry \& Berry, 1990). The results of our analysis show some support for this. Neighbors, which reflects a state looking to its bordering jurisdictions for policy solutions, were significant but negative. In comparison, region and national both showed significant and positive effects. These results confirm that policy learning of merit aid programs is occurring, but the diffusion is broader, in search of potential solutions. Reasoning for the difference in the directionality of these results is twofold. First, the rapid advancements in technology and the internet have expanded lawmakers' capacity to review possible policy solutions. No longer are lawmakers bound to information from neighboring states, but they may look at states all across the nation to see how they respond. Additionally, while the sign on the neighboring state diffusion variable may be negative, its significance still indicates that lawmakers are looking at neighboring states to determine policy solutions. If a state decides not to adopt a policy, even if all neighboring states have, such as Mississippi, this study still considers using learning to make an informed policy decision.

Aside from the effects of the external mechanisms, the results provide several other interesting findings. Considering the demands placed upon a state by its local governments, the number of counties was found to have no statistical impact. The numbers of municipalities and special districts, however, have been shown to have a significant effect. Our results show that as the number of municipalities within a state increases, its likelihood of adopting a merit aid program decreases. Alternatively, as the number of special districts grows, the likelihood of adoption increases. These results are somewhat surprising. Counties are administrative branches of the state, and states have been known to shift the burden of a program from the state onto its counties, freeing the state to focus on other issues (see McDonald and Gabrini, 2014). We had expected that more counties would allow for more distribution of programs, freeing the state to focus on state-wide initiatives, such as merit aid programming. For municipalities and special districts, the more governments within a state, the wider arrangement of services provided, allowing residents to choose their location based on the package of services rather than relying on the state. Although we found no evidence for this impact related to the number of counties, the negative effect from municipalities does offer support for the hypothesis. When special districts are utilized, it is an indication that there is no more slack in budgets for counties or cities to provide additional services, so special districts are set up to provide those services. 
Also of importance is the capacity of the state to afford a merit aid program. This financial capacity is reflected across the three ratios that depict fiscal health. Our results show that states consider the fiscal impact of policies, such as a merit aid program, when considering adoption. According to the estimates, the more fiscally healthy a state is more likely to adopt a program. This can be seen in the positive relationship between the efficiency ratio and program adoption and the negative relationship between debt service burden and adoption. For the efficiency ratio, a larger ratio suggests that a state either has additional revenue or lower expenditures. Similarly, as the debt service burden decreases, a state is either reducing its total debt or increasing its assets. In either case, the improved outcomes suggest the state has an improved budgetary capacity to pay for new programs, allowing funding for merit aid programs.

Politically, states whose legislatures have a Democratic majority (reflected in the variable Democratic legislature) are less likely to adopt a merit aid program. However, states with a Democratic governor are more likely to adopt. While this finding is contrary to general expectations regarding political parties and public goods and services, the impact of a Democratic legislature may be tied to the state's minority population. Based on our results, as the minority share of a state's population increases, so does the opportunity for the state to adopt a merit aid program. Given the connection between the Democratic party and minority support, the impact of a Democratic legislature and the size of the minority population may confound the others' effect. This possibility is worthy of study in future research.

The final set of variables is used to relate to the economic environment of residents. Income, GSP, and unemployment were all controlled for in the model. Of these variables, only income was significant. This runs counter to the reasoning many politicians have used to implement merit aid scholarships. Increasing income and lowering unemployment are lauded as the main reason to implement merit aid scholarships, but this model shows they are little more than talking points when making adoption decisions.

\section{DISCUSSION}

This study has investigated the drivers behind a state's decision to adopt a merit aid program. According to the literature, policy diffusion occurs when one government influences the actions of another government. This influence comes in various forms, including learning, competition, and normative pressures. These different influences work in congruence and influence the decision a government makes regarding a policy. The literature does start to diverge, though, when debating where diffusion mechanisms are internally or externally focused. Internal influences focus on the structure and politics of a government; whereas, external influences focus on the environment in which the state operates. To better understand these diffusion mechanisms, a review of merit aid programs across the fifty states in the U.S. was conducted. As has been discussed, the decision of a state to adopt a program is heavily influenced by the external mechanisms of competition and policy learning.

Although the variables of interest in this study provide insight into merit aid program adoption, these characteristics are likely to be found in other policy diffusion studies. Similar influences that affect merit aid programs are likely to be found in other policies regarding the distribution of public goods and services. For example, it is not extreme to think that the variables measured here and found significant would also affect pre-K education and affordable housing policies. As such, this study provides key insight into better understanding why some social support policies are adopted and others are not. Specifically, it provides the insight that there seems to be little relation between the reasoning behind adopting a policy and the talking points that are used to garner public support for the policy

In the policy narrative surrounding merit aid programs, scholarships are touted as a way to enroll underrepresented populations and grow an educated workforce within the state (Leeds \& DesJardins, 2015). We did find evidence that connects the minority population and educational attainment of a state to its likelihood of adoption, but there was no significant relationship between unemployment and adoption. While these are good talking points for the public, it is clear there are other environmental factors much more important. As Berry and Berry (2014) argue, governments are influenced by other governments in close geographical proximity. These geographical influences prove significant in this study, indicating that policymakers knew what was happening in neighboring states. As elected officials become aware of an 
issue raised by residents, they look for other jurisdictions that have adopted policies to solve similar problems. Thus, the newly adopted policy might not solve the issue raised by residents, but rather satisfices as a policy that appears to solve the issue and addresses resident concerns.

To better understand the divergence between the narrative and factors that drive a state to adopt and whether the adoption occurs, we looked at the predicted probability that a state would have a merit aid program over time. The results of this reflection are provided in Table 3 and Figure 2. The figure shows that in the early years of our analysis, states were unlikely to adopt based on the Innovation and Diffusion Framework mechanisms. In 1993, for instance, Georgia became the first state to adopt a merit aid program despite exhibiting a $0.00 \%$ likelihood of adoption. By 2003, however, states exhibited, on average, a $99.03 \%$ chance of having a merit aid program. In 2015 , the probability had risen to $99.98 \%$. To help place this into context, only 34 states $(68 \%)$ had chosen to adopt. Thus, despite the significance of our results, the findings suggest that there may be a failure within the Innovation and Diffusion Framework.

In the case of merit aid policy, the decision to innovate came from an influence outside of public policy's internal and external mechanisms. The diffusion mechanisms suggest that states should have adopted in subsequent years, but states have been holding out. What is driving the decisions of states to act outside of the framework? The framework does not provide sufficient clarity to understand outliers. Unfortunately, the innovation of a policy or program is generally done by an outlier.

The solution may come by pairing Berry and Berry's framework with other policy perspectives, such as the Narrative Policy Framework (see Shananhan, Jones, McBeth, \& Radaelli, 2018), the Multiple Streams Framework (MSF; see Herweg, Zahariadis, \& Zohlnhofer, 2018; Kingdon, 1984), and agendasetting (see Deters \& Falkner, 2021; Laage-Thomsen, 2021). In the context of merit aid adoption, MSF could be a sufficient tool to fill the limitations of innovation and diffusion and explain outlier behavior. According to Kingdon (1984), policy change occurs when a policy entrepreneur captures a policy solution and waits for a window of opportunity to push the solution through to adoption. The presence of a policy entrepreneur could explain why innovation occurs against all odds, and the absence of an entrepreneur may also explain why a state chooses not to adopt. In the case of merit aid programs, the entrepreneur behind the initial innovation was Governor Zell Miller. He encouraged the establishment of the state lottery and moved to use lottery funds as an educational enhancement tool.

TABLE 3

\section{PREDICTED PROBABILITIES}

\begin{tabular}{|c|c|c|c|}
\hline Variable & $+1 \%$ & $+5 \%$ & $+10 \%$ \\
\hline \multicolumn{4}{|c|}{ State Competition Variables } \\
\hline Attainment & 0.4371 & 0.4402 & 0.4441 \\
\hline Out of State & 0.4315 & 0.4256 & 0.4182 \\
\hline \multicolumn{4}{|l|}{ Policy Learning Variables } \\
\hline Neighbors & 0.4391 & 0.4379 & 0.4352 \\
\hline Region & 0.4312 & 0.4369 & 0.4440 \\
\hline National & 0.4333 & 0.4395 & 0.4474 \\
\hline \multicolumn{4}{|c|}{ Governmental Characteristics } \\
\hline Counties & 0.4357 & 0.4371 & 0.4387 \\
\hline Municipalities & 0.4402 & 0.4349 & 0.428 \\
\hline Special Districts & 0.4350 & 0.4368 & 0.4389 \\
\hline Efficiency Ratio & 0.4384 & 0.4439 & 0.4506 \\
\hline IGR Dependence Ratio & 0.4373 & 0.4372 & 0.4371 \\
\hline Debt Service Burden & 0.4332 & 0.4287 & 0.4232 \\
\hline \multicolumn{4}{|l|}{ Political Characteristics } \\
\hline Democratic Legislature & 0.4309 & 0.4283 & 0.4249 \\
\hline Democratic Governor & 0.4374 & 0.4378 & 0.4383 \\
\hline
\end{tabular}




\begin{tabular}{|c|c|c|c|}
\hline New Term & 0.4373 & 0.4373 & 0.4368 \\
\hline Unified System & 0.4371 & 0.4379 & 0.4388 \\
\hline \multicolumn{4}{|c|}{ Demographic Characteristics } \\
\hline Minority Population & 0.4356 & 0.4380 & 0.4411 \\
\hline Population Density & 0.4379 & 0.4378 & 0.4381 \\
\hline Incorporated Population & 0.4375 & 0.4382 & 0.4390 \\
\hline \multicolumn{4}{|l|}{ Economic Characteristics } \\
\hline Income & 0.4370 & 0.4347 & 0.4319 \\
\hline GSP & 0.4401 & 0.4634 & 0.4934 \\
\hline Unemployment & 0.4374 & 0.4375 & 0.4377 \\
\hline
\end{tabular}

Despite the problems associated with the Innovation and Diffusion Framework to capture outliers, the internal and external mechanisms provide broad strokes that point towards circumstances in which an outlier occurs. Kingdon (1984) notes that there is a stockpile of policy solutions that are being researched, debated, and revised at any point in time. What we find, and what our study adds to the literature on policy diffusion and higher education policy, is where governments look when they seek out those policies. Rather than competing regionally or nationally, state competition centers around neighboring communities, with states looking to those regional and national communities for their stockpile of policy solutions. More targeted research could look at how states become aware of regional and national solutions, which would add some much-needed clarity on how non-border diffusion occurs.

FIGURE 2

PROBABILITY OF ADOPTION OVER TIME

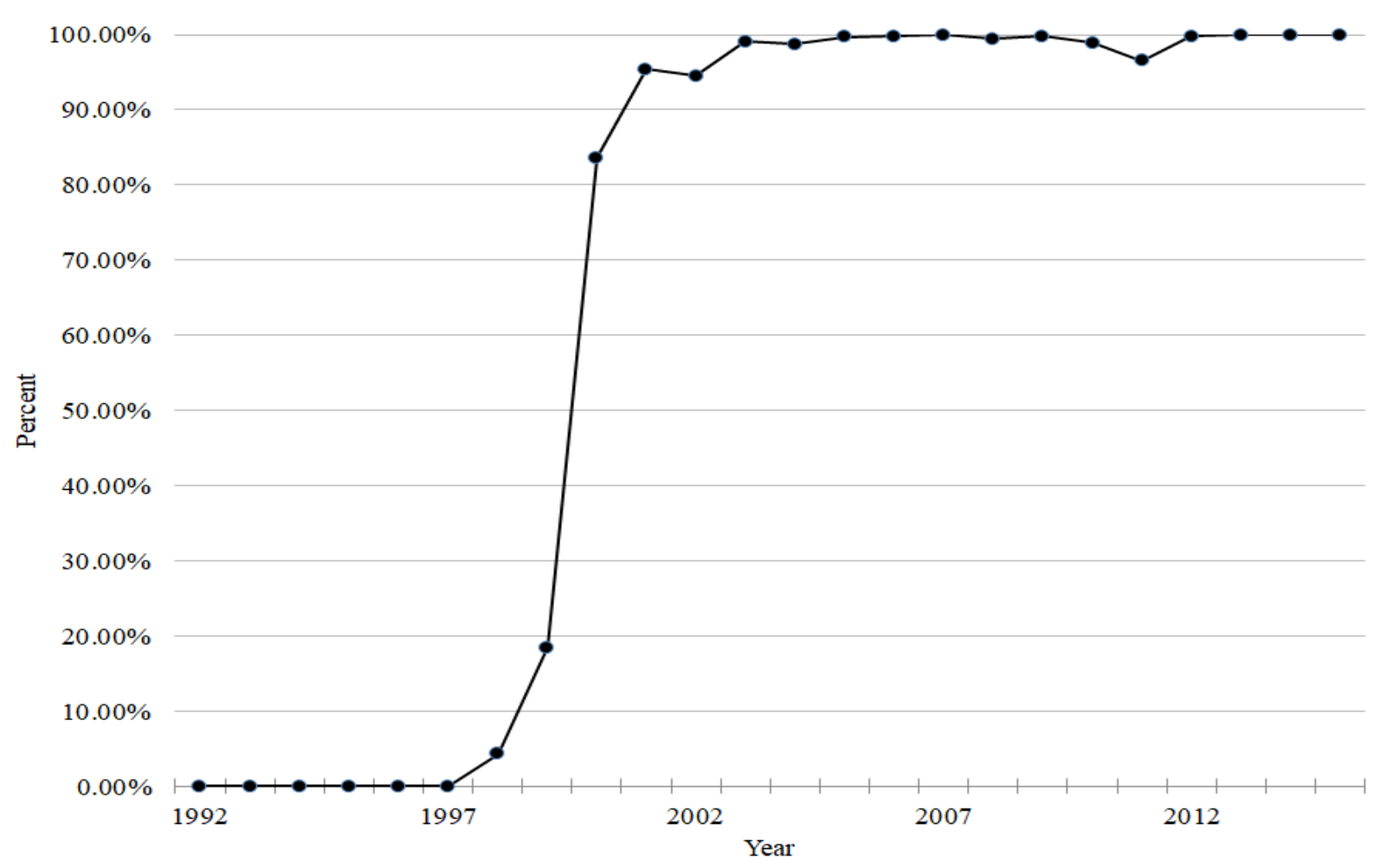

Our research results also open a question regarding why states do not do more to keep students in the state. Our estimates showed that as the share of students attending a college or university out of state 
increased, the likelihood that a state would adopt a policy such as merit aid to keep them in-state decreased. High school students that are higher achieving are more likely to have more university choices and are thus more likely to pursue a degree out of state. Why a state would not adopt a policy that encourages these students to stay in the state remains unknown. Suppose a state will not compete with its neighbors. In that case, it opens the possibility that universities in neighboring states may offer scholarships or tuition reductions as a way to entice the brightest away. Ultimately, the failure of a state to compete in this regard will leave it drained of a highly trained and educated workforce. This may explain why we found evidence that states are more likely to adopt a merit aid program when their educational attainment is low.

\section{CONCLUSION}

The growth in the cost of higher education, along with the decrease in available federal funding, has increased residents' calls for states to supplement higher education in some way. One way states have sought to do this is through merit aid scholarships, given to students based on their achievement in high school. Proponents claim that merit scholarships create a more educated workforce in the state and improve higher education attendance. These claims make merit aid programs seem like a desirable way to fund students pursuing higher education. However, little is known about why a state chooses to adopt a merit aid scholarship policy. This study sought to contribute to the understanding of policy diffusion using internal and external diffusion mechanisms from previous literature (see Berry \& Berry, 1990, 2018; Shipan \& Volden, 2008, 2012). These theories were tested using an event history analysis of all 50 states from 1992 to 2015 .

The findings in this study suggest that it is not enough to look at one set of diffusion mechanisms, but rather that internal and external mechanisms must be analyzed together. Even though technology has brought together information from across the country, geographical proximity continues to be a leading influence in policy diffusion. While these findings are important, they should be applied with caution. The results about diffusion mechanisms are limited by the ability to only review one policy at a time in these diffusion studies. Future research should continue to further the understanding of diffusion mechanisms by looking at other social policies and their adoption across states. These studies should account for the previously supported diffusion mechanisms and analyze the talking points that elected officials use to garner political support for a policy. By doing this, it is possible to understand better what mechanisms are actually present in the diffusion of a policy.

\section{ENDNOTES}

1. The four states who adopted merit aid programs only to repudiate the programs later are Illinois, Maryland, Michigan, and Washington.

2. For a more detailed discussion on the contribution of fiscal health to state policy and the complications of measuring fiscal health, see Maher and Nollenberger (2009), Maher, Stallman, Deller, and Park (2017), McDonald, Decker, and Johnson (2021), McDonald (2015, 2018), and Foged (2021).

\section{REFERENCES}

Angrist, J., \& Lavy, V. (2002). New evidence on classroom computers and pupil learning. The Economic Journal, 112(482), 735-765.

Baybeck, B., Berry, W.D., \& Siegel, D.A. (2011). A strategic theory of policy diffusion via intergovernmental competition. The Journal of Politics, 73(1), 232-247.

Becker, G.S. (1993). Human capital: A theoretical and empirical analysis with special reference to education. Chicago, IL: University of Chicago Press.

Berry, F.C., Berry, W.D., \& Foster, S.K. (1998). The determinants of success in implementing an expert system in state government. Public Administration Review, 58(4), 293-305. 
Berry, F.S., \& Berry, W.D. (1990). State lottery adoptions as policy innovations: An event history analysis. American Political Science Review, 84(2), 395-415.

Berry, F.S., \& Berry, W.D. (2014). Innovation and diffusion models in policy research. In P.A. Sabatier \& C.M. Weible (Eds.), Theories of the policy process (3rd ed., pp. 307-360). Boulder, CO: Westview Press.

Berry, F.S., \& Berry, W.D. (2018). Innovation and diffusion models in policy research. In C.M. Weible \& P.A. Sabatier (Eds.), Theories of the policy process (4th ed., pp. 253-300). New York, NY: Routledge.

Berry, W.D., \& Baybeck, B. (2005). Using geographic information systems to study interstate competition. American Political Science Review, 99(4), 505-519.

Boehmke, F.J., \& Witmer, R. (2004). Disentangling diffusion: The effects of social learning and economic competition on state policy innovation and expansion. Political Research Quarterly, 57(1), 39-51.

Checkland, K., Hammond, J., Coleman, A., Macinnes, J., Mikelyte, R., Croke, S., . . Allen, P. (2021). "Success" in policy piloting: Process, programs, and politics. Public Administration. https://doi.org/10.1111/padm.12790

Cohen-Vogel, L., Ingle, W.K., Levine, A.A., \& Spence, M. (2008). The "spread' of merit-based college aid: Politics, policy consortia, and interstate competition. Educational Policy, 22(3), 339-362.

Copeland, K.D., \& Mamiseishvili, K. (2017). The Arkansas lottery scholarship act: An examination of the policy design process. Educational Policy, 31(1), 108-136.

Cornwell, C., Mustard, D.B., \& Sridhar, D.J. (2006). The enrollment effects of merit-based financial aid: Evidence from Georgia's HOPE program. Journal of Labor Economics, 24(4), 761-786.

Decker, J.W. (2021). An (in)effective TEL: Why county governments do not utilize their maximum allotted property tax rate. Public Administration. https://doi.org/10.1111/padm.12756

Deters, H., \& Falkner, G. (2021). Remapping the European agenda-setting landscape. Public Administration, 99(2), 290-303.

Domina, T. (2014). Does merit aid program design matter? A cross-cohort analysis. Research in Higher Education, 55(1), 1-26.

Doyle, W.R. (2006). Adoption of merit-based student grant programs: An event history analysis. Educational Evaluation and Policy Analysis, 28(3), 259-285.

Dynarski, S. (2002). The consequences of merit aid (Working Paper No. W9400). Washington, DC: National Bureau of Economic Research.

Foged, S.K. (2021). Spending allocations during low and high fiscal stress: Priority setters and spending advocates in Danish municipalities, 2008-2015. Public Administration. https://doi.org/10.1111/padm.12759

Go, M.H. (2016). Building a safe state: Hybrid diffusion of building code adoption in American states. American Review of Public Administration, 46(6), 713-733.

Gormley, W. (1986). Regulatory issue networks in a federal system. Polity, 18(4), 596-620.

Gurin, P., Dey, E., Hurtado, S., \& Gurin, G. (2002). Diversity and higher education: Theory and impact on educational outcomes. Harvard Educational Review, 72(3), 330-367.

Heller, D.E. (2006). Merit aid and college access. In Symposium on the consequences of merit-based student aid. Madison, WI: University of Wisconsin-Madison, Wisconsin Center for the Advancement of Postsecondary Education.

Heller, D.E., \& Marin, P. (2002). Who should we help? The negative social consequences of merit scholarships (ERIC No. ED468845). Cambridge, MA: The Civil Rights Project.

Herweg, N., Zahariadis, N., \& Zohlnhofer, R. (2018). The multiple streams framework: Foundations, refinements, and empirical applications. In C.M. Weible \& P.A. Sabatier (Eds.), Theories of the policy process (4th ed., pp. 17-53). New York, NY: Routledge.

Hu, S., \& John, E.P.S. (2001). Student persistence in a public higher education system: Understanding racial and ethnic differences. The Journal of Higher Education, 72(3), 265-286. 
Kim, J., McDonald, B.D., \& Lee, J. (2018). The nexus of state and local capacity in vertical policy diffusion. American Review of Public Administration, 48(2), 188-200.

Kim, J., Shon, J., \& McDonald, B.D. (2021). Does school district board type affect fiscal conditions? Examining debt position. Public Performance \& Management Review. https://doi.org/10.1080/15309576.2021.1939738

Kingdon, J.W. (1984). Agendas, alternatives, and public policies. Boston, MA: Little, Brown.

Kolodner, M. (2015, June 22). States moving college scholarship money away from the poor, to the wealthy and middle class. The Hechinger Report. Retrieved May 21, 2016, from $\mathrm{http} / / /$ hechingerreport.org/states-moving-college-scholarship-money-away-from-the-poor-to-thewealthy-and-middle-class/

Laage-Thomsen, J. (2021). Professional expertise in policy advisory systems: How administrators and consultants built behavioral insights in Danish public agencies. Public Administration. https://doi.org/10.1111/padm.12725

Lacy, T.A., \& Tandberg, D.A. (2014). Rethinking policy diffusion: The interstate spread of "finance innovations." Research in Higher Education, 55(7), 627-649.

Leeds, D.M., \& DesJardins, S.L. (2015). The effect of merit aid on enrollment: A regression discontinuity analysis of Iowa's national scholars award. Research in Higher Education, 56(5), 471-495.

Long, B.T. (2004). How do financial aid policies affect colleges? The institutional impact of the Georgia HOPE scholarship. Journal of Human Resources, 39(4), 1045-1066.

Maher, C.S., \& Nollenberger, K. (2009). Revisiting Kenneth Brown's '10-point test.' Government Finance Review, 25(5), 61-66.

Maher, C.S., Ebdon, C., \& Bartle, J.R. (2020). Financial condition analysis: A key tool in the MPA curriculum. Journal of Public Affairs Education, 26(1), 4-10.

Maher, C.S., Stallman, J.I., Deller, S.C., \& Park, S. (2017). The effects of tax and expenditure limits on state fiscal reserves. Public Policy and Administration, 32(2), 130-151.

McDonald, B.D. (2015). Does the charter form improve the fiscal health of counties? Public Administration Review, 75(4), 609-618.

McDonald, B.D. (2017). Measuring the fiscal health of municipalities (Working Paper No. WP17BM1). Cambridge, MA: Lincoln Institute of Land Policy.

McDonald, B.D. (2018). Local governance the issue of fiscal health. State and Local Government Review, $50(1), 46-55$.

McDonald, B.D. (2019). The challenges and implications of fiscal health. South Carolina Journal of International Law and Business, 15(2), 78-99.

McDonald, B.D. (2021). A human capital model of the defense-growth relationship. The Social Science Journal, 58(2), 247-261.

McDonald, B.D., \& Gabrini, C.J. (2014). Determinants of charter county decisions: An event history analysis of Florida counties. Journal of Public Administration Research and Theory, 24(3), $721-$ 739.

McDonald, B.D., Decker, J.W., \& Johnson, B.A.M. (2021). You don't always get what you want: The effect of financial incentives on state fiscal health. Public Administration Review, 81(3), 365-374.

McLendon, M.K., Hearn, J.C., \& Deaton, R. (2006). Called to account: Analyzing the origins and spread of state performance-accountability policies for higher education. Educational Evaluation and Policy Analysis, 28(1), 1-24.

McLendon, M.K., Heller, D.E., \& Young, S.P. (2005). State postsecondary policy innovation: Politics, competition, and the interstate migration of policy ideas. Journal of Higher Education, 76(4), 363-400.

Medoff, M.H., Dennis, C., \& Stephens, K. (2011). The impact of party control on the diffusion of parental involvement laws in the U.S. states. State Politics \& Policy Quarterly, 11(3), 325-347.

Mintrom, M. (1997). Policy entrepreneurs and the diffusion of innovation. American Journal of Political Science, 41(3), 738-770. 
National Center for Education Statistics. (2019). Digest of education statistics, 2017. Washington, DC: U.S. Department of Education.

National Conference of State Legislatures (2019). State Partisan Composition. Retrieved from https://www.ncsl.org/research/about-state-legislatures/partisan-composition.aspx

Ness, E.C. (2010). The politics of determining merit aid eligibility criteria: An analysis of the policy process. The Journal of Higher Education, 81(1), 33-60.

Nicholson-Crotty, S. (2009). The politics of diffusion: Public policy in the American states. The Journal of Politics, 71(1), 192-205.

Perna, L.W., \& Finney, J.E. (2014). The attainment agenda: State policy leadership in higher education. Baltimore, MD: Johns Hopkins University Press.

Perna, L.W., \& Jones, A.P. (Eds.). (2013). The state of college access and completion: Improving college success for students from underrepresented groups. New York, NY: Routledge.

Pingel, S., Sponsler, B.A., \& Holly, N. (2018). Redesigning state financial aid: Principles to guide state aid policymaking. Denver, CO: Education Commission of the States.

Prillaman, S.A., \& Meier, K.J. (2014). Taxes, incentives, and economic growth: Assessing the impact of pro-business taxes on U.S. state economies. The Journal of Politics, 76(2), 364-379.

Savvides, A., \& Stengo, T. (2009). Human capital and economic growth. Stanford, CA: Stanford University Press.

Scott-Clayton, J. (2011). On money and motivation: A quasi-experimental analysis of financial incentives for college achievement. Journal of Human Resources, 46(3), 614-646.

Scott-Clayton, J. (2015). The role of financial aid in promoting college access and success: Research evidence and proposals for reform. Journal of Student Financial Aid, 45(3), 6-22.

Shanahan, E.A., Jones, M.D., McBeth, M.K., \& Radaelli, C.M. (2018). The narrative policy framework. In C. M. Weible \& P. A. Sabatier (Eds.), Theories of the policy process (4th ed., pp. 183-224). New York, NY: Routledge.

Shipan, C.R., \& Volden, C. (2008). The mechanisms of policy diffusion. American Journal of Political Science, 52(4), 840-857.

Shipan, C.R., \& Volden, C. (2012). Policy diffusion: Seven lessons for scholars and practitioners. Public Administration Review, 72(6), 788-796.

Sjoquist, D.L., \& Winters, J.V. (2014). Merit aid and post-college retention in the state. Journal of Urban Economics, 80, 39-50.

Sjoquist, D.L., \& Winters, J.V. (2015). State merit-based financial aid programs and college attainment. Journal of Regional Science, 55(3), 364-390.

Volden, C, Ting, M.M., \& Carpenter, D.P. (2008). A formal model of learning and policy diffusion. American Political Science Review, 102(3), 319-332.

Walker, J.L. (1969). The diffusion of innovations among the American states. American Political Science Review, 63(3), 880-899.

Walker, R.M., Avellaneda, C.N., \& Berry, F.S. (2011). Exploring the diffusion of innovation among high and low innovative localities: A test of the Berry and Berry model. Public Management Review, 13(1), 95-125.

Young, S.L., Wiley, K.K., \& Searing, E.A.M. (2020). "Squandered in real time”: How public management theory underestimated the public administration-politics dichotomy. American Review of Public Administration, 50(6-7), 480-488. 